\title{
NECESSARY FICTIONS W POLSKIEJ PROZIE PO 1989 ROKU 1
}

\author{
EMILIA KLEDZIK ${ }^{2}$ \\ (Uniwersytet im. Adama Mickiewicza w Poznaniu)
}

\begin{abstract}
Słowa kluczowe: postkolonializm, sarmatyzm, necessary fiction, polska proza po 1989 roku, transformacja
\end{abstract}

Key words: postcolonial studies, sarmatism, necessary fiction, Polish fiction after 1989, transformation

\begin{abstract}
Abstrakt: Emilia Kledzik, NECESSARY FICTIONS W POLSKIEJ PROZIE PO 1989 ROKU. „PORÓWNANIA" 13, 2013, t. XIII, s. 127-142. ISSN 1733-165X. Termin Homiego Bhabhy „necessary fictions" objawił polskim sympatykom teorii postkolonialnej Dariusz Skórczewski w polemice z Niesamowitą Stowiańszczyzną Marii Janion, nie zgadzając się z zaproponowaną przez badaczkę krytyką roli chrześcijaństwa w kształtowaniu polskiej tożsamości narodowej. Bhabha przekonuje, że istnieje inna droga reprezentacji podmiotu kolonialnego niż ta ufundowana na splocie realizmu i historyzmu - taka, która zakłada, że rzeczywistość nie jest „dana”, lecz "stworzona”, w oparciu o krytykę reprezentacji. „Necessary fiction” jest rodzajem „wytwarzania tradycji” osadzonej w historycznym, a także historycznoliterackim i kulturowym continuum. Wytycza obiektywny porządek rzeczy - tak historycznie, jak kulturowo - i w tym sensie opowiada o rzeczywistości, a nawet ją projektuje. Autorka przyjrzy się trzem sposobom konstruowania takiej fikcji ciągłości w polskiej literaturze i krytyce literackiej po 1989 roku: tropom słowiańskim, tropom sarmackim oraz dyskusji nad współmiernością przełomów politycznych 1918 i 1989 roku.Składnik „necessary fictions” -nakaz dziedziczenia postaw światopoglądowych przestrzega Bhabha, może skutkować nie tylko ograniczeniem refleksji nad literaturą do kwestii pozaestetycznych, ale także zakonserwowaniem resentymentalnego kompleksu Zachodu.
\end{abstract}

\footnotetext{
Abstract: Emilia Kledzik, NECESSARY FICTIONS IN POLISH PROSE AFTER 1989. "PORÓWNANIA" 13, 2013, Vol. XIII, p. 127-142. ISSN 1733-165X. The term „necessary fiction” was presented to the Polish postcolonial theory followers by Dariusz Skórczewski in his polemic with Niesamowita Stowiańszczyzna by Maria Janion. He disagreed with Janion's vision of the role

${ }^{1}$ Niniejsza publikacja współrealizuje projekt NPRH „Dyskurs postkolonialny w Europie Środkowo-Wschodniej 1991-2011" (nr 12H 110018 80).

2 Correspondence Address: emilia.kledzik@gmail.com
} 
of Christianity in forming the Polish national identity. Bhabha argues that there is another way of presenting the postcolonial subject than the one founded on the combination of realism and historicism- the one, that assumes reality as given, but created on the basis of the criticism of representation. Necessary fiction is a way of "creating the tradition" based on historical, literary historical and cultural continuity. It shows the objective order of things - historically and culturally - and in this way it describes the reality and even designs it. The author observes three way of constructing such a fiction of continuity in the Polish prose and literary criticism after 1989: the Slavonic trail, the Sarmatian trail and the discussion about the similarities between political breakthroughs of 1918 and 1989. Bhabha warns that the component of "necessary fictions" - the imperative to pass down the values - may result not only with limiting literary criticism to nonaesthetic questions, but also with preserving the resentimental, Western complex.

Historia „necessary fictions” w polskim dyskursie humanistycznym nie jest skomplikowana. Terminu - autorstwa Homiego Bhabhy -w rodzimej debacie postkolonialnej pierwszy raz użył Dariusz Skórczewski w polemice z Niesamowita Słowiańszczyzna Marii Janion, opublikowanej w 2008 roku na łamach "Porównań" Lubelski badacz, nie zgadzając się z zaproponowaną przez Janion krytyką roli chrześcijaństwa w kształtowaniu polskiej tożsamości narodowej, pisał:

Niesamowita Słowiańszczyznę można uznać za swoisty, wysublimowany przejaw tego, co Homi Bhabha nazwał "necessary fictions”- postkolonialnej potrzeby wymyślania mitów w celu utwierdzenia się w swojej podmiotowości i umocnienia przez to swojej autochtonii ${ }^{3}$.

W niedawno wydanej rozprawie pt. Teoria - literatura - dyskurs. Pejzaż postkolonialny ten sam uczony, postulując konieczność ponownego przemyślenia dziedzictwa romantycznego, zaproponował opozycję pomiędzy pozytywnie wartościowanymi „mitami źródłowymi”, w stronę których podąża szeroko pojęta myśl romantyczna, a resentymentalną „necessary fiction” mesjanizmu. Takimi „koniecznymi fikcjami/narracjami” - pisze Skórczewski - „karmią się wszystkie społeczeństwa kolonialne, dopóki nie uporają się z psychologicznymi residuami obcej hegemonii i własnego upodrzędnienia"4. Literackie i krytycznoliterackie pozorne spojrzenie wstecz maskuje więc faktyczny konstrukt, jakim jest narracja o funkcji kompensacyjnej. Zadanie mitu źródłowego stanowi zaś nie tyle zaleczenie kolonialnej zadry, ale ufundowanie "podmiotu narodowego" na tle innych rodzących się wspólnotowych dyskursów tożsamościowych ${ }^{5}$.

${ }^{3}$ D. Skórczewski, Trudności z tożsamościa. Na marginesie Niesamowitej Słowiańszczyzny. „Porównania" 2008, nr 5, s. 140.

4 D. Skórczewski, Teoria - literatura - dyskurs. Pejzaż postkolonialny. Lublin 2013, s. 192

${ }^{5}$ Ibidem, s. 139. 
Czy taka opozycja może się obronić? Czy konstruowanie historii w narracjach społeczeństw postkolonialnych obligatoryjnie nie wiąże się ze swoistą „koniecznością" wskazania na historyczną ciągłość, która zadośćuczynić ma czas, kiedy narracja dominująca tworzyła inną opowieść, będącą legitymizacją zawłaszczenia? Czy problem nie leży raczej w absolutyzacji owej „konieczności”, czyli - inaczej mówiąc - źle postawionym pytaniu o „wiarogodność” takiej opowieści? Czyż w słowo fiction, jeśli pozbawić je negatywnych konotacji polskiego odpowiednika fikcja, nie oznacza po prostu literatury z jej kreacyjnym potencjałem? ${ }^{6}$

Sądzę, że Homi Bhabha w cytowanym przez Skórczewskiego w „Porównaniach" artykule pt. Representation and the Colonial Text: A Critical Exploration of Some Forms of Mimeticism dotyka właśnie problemu subtelnej różnicy, która dzieli polską „fikcję" od angielskiej „fiction”.W języku polskim zjawisko „fikcjonalności” deprecjonuje tekst i okalecza go, lokując "prawdę" i "sens" po stronie wciąż nieuchwytnej rzeczywistości ${ }^{7}$. W przekonaniu Bhabhy tradycyjne modele historycznoliterackie - od G. Lukácsa do E. Auerbacha - są ufundowane na takiej mimetycznej koncepcji literatury, zgodnie z którą utwór literacki motywowany jest „możliwością historii literatury, toczącej się dzięki progresywnemu odkryciu esencjonalnie niezapośredniczonej natury rzeczywistości w jej dziełach" $8 \mathrm{~W}$ jego opinii, te uniwersalizujące projekty, które deprecjonują fiction na rzecz fikcji oparte są na więzi "pomiędzy historyzmem a realizmem, pomiędzy wiarygodnością linearnego porządku a spójnością historii i bezpośredniej obecności realnego w literaturze" ${ }^{\prime \prime}$. A przecież - argumentuje Bhabha głosem antykolonialistów

niezapośredniczona rzeczywistość, którą $\mathrm{w}$ idealnym modelu musi odsłonić autentyczna tradycja literacka - oznaka jej oryginalności - nie może zostać zapisana w języku i literaturze obciążonej kolonializmem. Historyczne i ideologiczne determinanty zachodniej narracji - burżuazja, indywidualizm, organicyzm, liberalny humanizm, autonomia, postęp - nie są w stanie w taki sam sposób odbijać na przykład karaibskiego świata... Dyskursy i instytucje literatury angielskiej mogą jedynie zamglić i rozproszyć światło, które rzuca cień na obcą kulturę ${ }^{10}$.

6 Por. J. Culler, Teoria literatury. Krótkie wprowadzenie. Przeł. M. Bassaj. Warszawa 2002, s. 41-43.

7 Por. A. Łebkowska, Fikcja jako możliwość. Z przemian prozy XX wieku. Kraków 1998.

${ }^{8} \mathrm{H}$. Bhabha, Representation and the Colonial Text: A Critical Exploration of Some Forms of Mimeticism. W: The Theory of Reading. Ed. F. Gloversmith. Brighton 1989, p. 94. („A possibility of a history of literature driven forward by the progressive discovery of the essentially unmediated nature of reality in its works.")

9 Ibidem, s. 95.

${ }^{10}$ Ibidem. (,(..) unmediated reality that an authentic literary tradition must ideally reveal - the mark of its originality - it is argued, can hardly be written in a language and literature of colonial imposition. The historical and ideological determinants of Western narrative - bourgeois individualism, organicism, liberal humanism, autonomy, progression - cannot adequately reflect, for instance, 
Bhabha przekonuje, że istnieje inna droga reprezentacji podmiotu kolonialnego, która pozwala ominąć „zmowę historyzmu i realizmu”"11 W oparciu o krytykę reprezentacji. Ów historyzm i realizm, rozwój w kierunku „prawdy”, to:

historyczne i ideologiczne produkcje pozbawione jakiejkolwiek konieczności, którą sobie przypisują. To konieczne fikcje [necessary fictions] które w tragiczny sposób za bardzo uwierzyły w swoją konieczność, a za mało w swoją własną fikcjonalność. [podkreślenie - E.K] ${ }^{12}$

W ujęciu Bhabhy „necessary fictions” są więc funkcją lektury krytycznej, która absolutyzuje pojęcie "autochtoniczności", a jednocześnie zaciera ujawniającą się $\mathrm{w}$ tekście naturę podmiotu postkolonialnego - podmiotu różnicy. Takie fikcje są pozornie „niezapośredniczone i uniwersalne"13, kładą nacisk na kulturową ciągłość, konstruowaną wobec orientalizujących fikcji kolonizatora.Błąd leży jednak nie po stronie „fikcjonalności”, lecz „konieczności”, która jest własnością ich recepcji. „Necessary fictions” są dla odbiorców poręcznym narzędziem odbudowy skolonizowanej tożsamości. To rodzaj „wytwarzania tradycji”, która jest osadzona w historycznym continuum, totalna i nieznosząca sprzeciwu. Wytycza obiektywny porządek rzeczy - tak historycznie, jak kulturowo - i w tym sensie opowiada o rzeczywistości, a nawet ją projektuje. Mówi o przeszłości i przyszłości wspólnoty, pokazuje możliwe wybory i sugeruje decyzje, grozi konsekwencjami, dokonuje apoteoz i detronizacji. Do jej interpretacji przydaje się "kulturologiczny” komentarz, dzięki któremu czytelnik może przyporządkować ją do odpowiedniej debaty społecznej: o równouprawnieniu płci, o roli chrześcijaństwa w polskiej kulturze, o pożądanym modelu ustroju państwa. „Necessary fiction” ogranicza refleksję o literaturze do kategorii „zaangażowania”, a zatem kwestii pozaestetycznych, co skutkuje wtórnością $\mathrm{w}$ reprodukowaniu społeczeństwa mentalnie skolonizowanego i - jak przekonuje Bhabha - tłumi głos postkolonialnej różnicy.

Niesamowita Stowiańszczyzna dotyka zaledwie jednego z kontekstów literatury najnowszej, które mogą przypominać o polskich postkolonialnych „necessary fiction". Płodnym gruntem dla takich esencjalizujących uporządkowań są również - obok utraconej słowiańskości -takie „wielkie” tematy literatury polskiej, jak prowincja, opór wobec zachodniego modelu kulturowego, wyraziście przeciwstawianego tradycyjnemu modelowi relacji międzyludzkich (kryzys rodziny), sarmatyzm i kryzys tzw. paradygmatu romantycznego. Wszystkie te zjawiska

the Caribbean environment... The discourses and institutions of English Literature can only provide a dim and refracted light, that casts a shadow on an alien culture.")

11 Ibidem, s. 96.

12 Ibidem, s. 97. („(..) historical and ideological productions without any of the inevitability that they claim. They are necessary fictions that tragically believed too much in their necessity and too little in their own fictionality.")

${ }^{13}$ Ibidem. 
odnaleźć można w refleksji krytycznoliterackiej po 1989 roku, gdzie pełnią funkcje porządkujące i interpretacyjne. Celem niniejszego tekstu jest zaprezentowanie trzech wizji ciągłości, które wyłoniły się na polskiej mapie historycznoliterackiej po przełomie przy wsparciu krytyki literackiej: tropów słowiańskich, tropów sarmackich i tropów dwudziestolecia międzywojennego.

\section{TROPY SŁOWIAŃSKIE}

Choć decyzja Dariusza Skórczewskiego by użyć pojęcia „necessary fictions” w odniesieniu do książki krytycznoliterackiej może budzić kontrowersje, szerszy kontekst tego zastosowania wydaje się czytelny: rozprawa Marii Janion jako pierwsza bodaj raz historii polskiej krytyki twórczo wyzyskała koncepcję Edwarda Saida, stawiając sobie za cel wydobycie "skolonizowanego dziedzictwa" kultury słowiańskiej, która w średniowieczu miała zostać stłumiona przez ideę latinitas, przymusowej chrystianizacji. Głosy owej wypartej pierwotnej kultury słyszeli i przekuwali w materię literacką pisarze romantyczni; sporadycznie powracają one $\mathrm{w}$ polskiej literaturze najnowszej. $\mathrm{W}$ takiej adaptacji postkolonialnego instrumentarium widzi Dariusz Skórczewski po pierwsze, błąd metodologiczny (lustrem średniowiecza staje się dla Janion romantyzm), a po drugie - restytucję skompromitowanego, anachronicznego mitu pansłowiańskiego"14. „Konieczność” fikcji prezentowanych przez autorkę Niesamowitej Stowiańszczyzny polega na poddawaniu literatury romantycznej lekturze „zaangażowanej”, wpisaniu jej w porządek powrotu do kulturowej oryginalności, co prowadzi do zakonserwowania resentymentalnego, postkolonialnego kompleksu Zachodu.

Maria Janion, poszukując śladów przywracania skolonizowanego słowiańskiego dziedzictwa zaledwie wspomina o literaturze najnowszej - przywołując pansłowiański projekt Mariusza Wilka15. Tymczasem słowiańskie reminiscencje $\mathrm{w}$ prozie po 1989 roku pojawiają się także $\mathrm{w}$ literaturze feministycznej i pełnią $\mathrm{w}$ niej rolę - jak się wydaje - alternatywnej wobec chrześcijańskiej, racjonalnej, patriarchalnej ścieżki inicjacji kobiecych bohaterek. „Słowiańskość” utożsamiana jest z tajemnicą, sferą popędów, żywiołami chtonicznymi, niebezpieczeństwem, wiedzą tajemną. Dostęp do niej mają bohaterki pełniące role mentorek, obdarzone szczególną wrażliwością, talentami artystycznymi lub dokonujące introspekcji. Słowiańskość konotuje matriarchat (sic!), pierwotność, zmysłowość i seksualność. Przestrzeń, która symbolicznie się z nią wiąże to podziemie, las, góra. Kontakt z takim miejscem oznacza dostęp do źródła energii twórczej, inspirację do wglądu, zachętę do wejścia w dorosłość.

\footnotetext{
${ }_{14}$ D. Skórczewski, Na marginesie..., op. cit., s. 133 i 138.

${ }^{15}$ M. Janion, Niesamowita Stowiańszczyzna. Fantazmaty literatury. Kraków 2001, s. 235-240.
} 
Dwie sceny z Panny Nikt Tomka Tryzny rozgrywają się na Ślęży - górze stanowiącej domniemany ośrodek solarnego kultu Ślężan - wymarłego wraz z nastaniem na tych ziemiach chrześcijaństwa na przełomie X i XI wieku. W pierwszej z nich główne bohaterki - narratorka Marysia i jej charyzmatyczna koleżanka kompozytorka Katarzyna, wybierają się na spacer do prastarych kamiennych rzeźb niedźwiedzia i panny z rybą. „Kasia bardzo lubi tutaj przychodzić, bo w tym półmroku i chłodzie przychodzą jej najlepsze pomysły na muzykę"16 - wyjaśnia narratorka. Potem następuje opis pierwotnego obrzędu:

Już po chwili wokół posągu zaroiło się od strasznych, brodatych ludzi w skórzanych ubraniach nabijanych błyszczącymi ćwiekami, uzbrojonych w topory i łuki. Przyprowadzili ze sobą piękną, młodą dziewczynę. Była naga i związana sznurami. Dziewczyna krzyczała w niezrozumiałym języku, błagała o litość. Stanął nad nią wysoki starzec o rozwianych, siwych włosach. Uderzył ją maczugą w głowę. Dziewczyna upadła. Wtedy brodacze poćwiartowali toporami jej ciało, pozatykali krwawe szczątki na ostrza dzid i wznieśli je ku głowie posągu, krzycząc chórem „Omni moa aaa! Omni moa aaa! Ooo aaa ${ }^{17}$.

Wizja tego rytuału, który - jak się zdaje - ma oddawać cześć bogu słońca, a także oddziaływanie miejsca, wywołują u narratorki halucynacje i stany lękowe. Kiedy pod koniec powieści wraca na Ślężę, w poszukiwaniu przyjaciółki, która jak przypuszcza - przeżyła załamanie nerwowe, przy pozostałościach kamiennych wałów spotyka tajemniczą postać, która roztacza przed nią paradoksalne wizje jej przyszłości i uświadamia, że powinna dokonać wyboru:

- Widzisz tę ścieżkę?

Patrzę za jego palcem.

- Widzę.

- To ścieżka Majki. Jeżeli nią pójdziesz, w sopel lodu z gorąca zamarzniesz. Spójrz teraz tam...

- Aha - mówię - widzę.

- To jest ścieżka Minki. Tam będzie ci tak zimno, że jak ćma się spalisz. A tutaj zaczyna się ścieżka Marysi. Wije się spiralą wokół góry. To bardzo długa ścieżka, ale jeśli miałbym ci coś radzić, to powiedziałbym: idź nią Marysiu. Tą ścieżką dojdziesz na pewno ${ }^{18}$.

Wybór pomiędzy Majką, Minką i Marysią jest dla narratorki decydujący z punktu widzenia jej dorosłości i samodzielności. Podobne wizje znajdziemy w np. w powieści Izabeli Filipiak pt. Absolutna amnezja, gdzie przestrzenią w której główna bohaterka - Marianna - doświadcza kontaktu ze "pierwotnością” są ota-

\footnotetext{
16 T. Tryzna, Panna Nikt. Warszawa 1993, s. 200.

17 Ibidem.

18 Ibidem, s. 432-433.
} 
czające jej osiedle, skryte w lasach bunkry - „pozostałości ostatniej wojny"19. Podobnie jak Ślęża w powieści Tryzny - te „odsłonięte po części korytarze"20. to rejon panowania męskiej, patriarchalnej obyczajowości. Na toposie kathabasis oparta jest również powieść Olgi Tokarczuk pt. Anna In w grobowcach świata. Przedchrześcijańskie głosy usłyszymy także $\mathrm{w}$ dziejących się $\mathrm{w}$ okolicy Ślęży powieściach Joanny Bator. I choć słowiańskość nie jest w obu tych utworach wskazana expressis verbis, pojawia się $\mathrm{w}$ nich temat wypartej, intuicyjnej, pradawnej mądrości, która konstytuuje się wbrew logosowi i chrześcijańskiemu ratio.

\section{TROPY SARMACKIE}

Amerykańska slawistka Ewa Thompson, autorka rozprawy o rosyjskich literackich praktykach orientalizujących, redaktorka naczelna pisma "Sarmatian Review" w 2008 roku na łamach „Dziennika” ogłosiła tekst zatytułowany Sarmatyzm i postkolonializm, w którym przedstawiła opozycję literatury przedrozbiorowej, którą jej w opinii cechuje "normalność”, wobec przesiąkniętej resentymentem literatury porozbiorowej21. Ów resentyment definiuje badaczka następująco: "to zgoda na cierpiętnictwo, poczucie, że jest się poniżonym przez los i ludzi, to chroniczne litowanie się nad sobą, przyjęcie postawy ofiary. Przekonanie, że jest się niesprawiedliwie pokrzywdzonym, towarzyszy mu na zasadzie naczyń połączonych"22. To, zdaniem Thompson, cecha dyskursu narodów skolonizowanych, „choroba literatury”, która „zatraciła zdolność do smakowania sukcesu i generowania radości z osiągniętych celów” ${ }^{23}$. W literaturach „zwycięzców historii” natomiast znaleźć można raczej "satysfakcję z wygranej w miejsce monotonnego smaku przegranej" 24 . Ma więc najnowsza literatura polska dwa ważne wzorce: pierwszym jest entuzjazm, optymizm i umiłowanie świata Jana Kochanowskiego i Jana Chryzostoma Paska, drugim-"literatura zwycięzców" - Rosji, USA, Europy Zachodniej w „której klęska produkuje pozytywne osiągnięcia”. Głównym antidotum na polski kompleks postkolonialny - i to owo antidotum ośmielam się nazwać „necessary fiction" - jest jednak kultura sarmacka, którą Thompson definiuje następująco:

Sarmatyzm nie jest zorientowany ani na podboje, ani na podporządkowanie się cesarzowi, zamiast tego ceni republikanizm. Podłożem tego rodzaju postaw jest akceptacja

19 I. Filipiak, Absolutna amnezja. Warszawa 1995, s. 13.

20 Ibidem, s. 14.

${ }^{21}$ E. Thompson, Sarmatyzm i postkolonializm, http://wiadomosci.dziennik.pl/wydarzenia/artyku ly/193060,sarma tyzm-i-postkolonializm.html, data dostępu: 20.04.2013.

22 Ibidem.

23 Ibidem.

${ }^{24}$ Ibidem. 
rzeczywistości ze wszystkimi jej niedostatkami oraz założenie, że w ramach tej rzeczywistości pewne rzeczy są normalne i możliwe, a inne nienormalne i niemożliwe ${ }^{25}$.

Szkopuł tkwi, jak sądzę, w epitetach „normalny” i „możliwy”. Wzorzec, który wytycza ową "normalność” wyznaczają wszak - jak wiemy nie tylko z oświeceniowego stereotypu, ale z także z brawurowej książki Przemysława Czaplińskiego pt. Resztki nowoczesności, takie atrybuty jak: ksenofobia, nietolerancja religijna i patriarchalizm, walka z liberalizmem, kosmopolityzmem, i laickością ${ }^{26}$. Od Nietzscheańskiego resentymentu chroni wizję Thompson w zasadzie tylko brak autorefleksji. Sarmatyzm w tej formie jest zaprzeczeniem nowoczesności - przekonuje Czapliński ${ }^{27}$. Kto nie wierzy, niech posłucha (ironicznego?) głosu Szczepana Twardocha z tekstu z 2006 roku opublikowanego na łamach „Opcji” o symptomatycznym tytule Wyznania prowincjusza:

Jako prowincjusz względem stolicy świata, wijącej się w tunelach metra, w katedrach betonowych ścian skyscrapers jestem, razem z wszystkimi Europejczykami, w oczywisty sposób odsunięty od najściślejszego pulsu świata; większość tego, co ważne, dzieje się za oceanem. Bardzo mi to odpowiada, jako, że moje zainteresowania koncentrują się na dobrej, śląskiej kuchni i dobrym piwie, a postęp ważny jest dla mnie o tyle, o ile może wnieść nową, interesującą metodę wytapiania smalcu, którego to specjału produkcja, ze względu na listopadową porę, jest dla mnie ostatnio najpoważniejszym wyzwaniem. Jako prowincjusz w kontekście Europy, jestem z mojego prowincjonalizmu bardzo zadowolony, gdyż za sprawą wielkiego Księcia Kościoła, Stefana kardynała Wyszyńskiego, w moim prowincjonalnym kraju Kościół Katolicki ma się bardzo dobrze, najlepiej z wszystkich krajów Europy, czego nie jest w stanie zniweczyć nawet kunktatorska postawa niektórych hierarchów w kwestii oczyszczenia struktur kościelnych z komunistycznych agentów. Co za tym idzie, ta prowincja Europy między Odrą a Bugiem wolna jest na szczęście od urzędników, gotowych udzielić ślubu panom, znajdującym upodobanie w zadkach innych panów, a, co ważniejsze, wolność słowa oznacza coś innego niż "możesz mieć dowolne poglądy, pod warunkiem, że będą to poglądy liberal$n^{\prime \prime}$ - ośmielam się twierdzić, że Polska jest w tej chwili, obok USA, krajem o największej różnorodności poglądów prawdziwie obecnych w debacie publicznej. W Starej Europie spektrum debaty zamyka się między poglądami skrajnie lewackimi a umiarkowanie centrowymi - wszystko inne skazane jest na egzystowanie razem z wyznawcami kultu Elvisa i UFO. W Polsce zaś, w debata publiczna jest prawdziwie zdywersyfikowana, mimo piętnastu lat starań Adama Michnika, dążącego do europejskiego wzorca debaty, opartego ściśle na wzorcach radzieckich - publicznie obecne są poglądy, za jakie w Szwecji idzie się do więzienia, a we Francji na, używając określenia Cezarego Michalskiego, pluszowy krzyż zapomnienia i marginalizacji. W efekcie, od skrajnego lewactwa Szczuki, przez lewaka Żakowskiego, umiarkowanych publicystów

\footnotetext{
25 Ibidem.

26 P. Czapliński, Resztki nowoczesności. Dwa studia o literaturze i życiu. Kraków 2012, s. 112-120.

27 Ibidem, s. 104-110.
} 
centrum, w gazetach pisywać może również Korwin-Mikke, Michalkiewicz czy wreszcie ultrakonserwatysta Jacek Bartyzel. A to mi odpowiada, ponieważ jestem liberałem i lubię zróżnicowanie debaty i cenię wolność słowa, tak obrzydliwie zgwałconą w zwałaszałej Starej Europie ${ }^{28}$.

Laureat paszportu „Polityki” za powieść o kryzysie męskości, prezentuje tzw. nieupiększony podmiot sarmacki, który nie wstydzi się swojej ksenofobii i zaściankowości, jest zmysłowy, kulinarny, cielesny, homofobiczny, rozkochany w codzienności, masowy, epifanijny i przedkartezjański.

Ową sarmacką „normalność” wydrwiwał Witold Gombrowicz i to ona stała się materią kampowych eksperymentów Michała Witkowskiego. Ja chciałabym oddać głos innemu polskiemu pisarzowi - Dawidowi Bieńkowskiemu - który z sarmackością expressis verbis pojedynkuje się w swojej ostatniej powieści pt. Biato-czerwony, ale wokół ewokowanego przez nią światopoglądu osnuwa także tę wcześniejszą, pt. Nic. Czynię to także dlatego, że w studium o postsarmatyzmie Przemysław Czapliński w zasadzie pominął twórczość Bieńkowskiego, a komentując w kilku zdaniach powieść Biało-czerwony skupił się tylko na swoistej wolcie sarmatyzmu, która w tym utworze, zdaniem poznańskiego badacza, czyni z sarmatyzmu sojusznika nowoczesności. Ja natomiast widzę w Bieńkowskim wytrwałego tropiciela śladów owego nieupiększonego sarmatyzmu w wizerunkach postaci borykających się z trudnym początkiem lat dziewięćdziesiątych. Bieńkowski z dociekliwością godną psychoanalityka tropi skutki owego resentymentu, który Thompson nazywa polskim kompleksem postkolonialnym. Powrót sarmackiego wzorca kulturowego w latach dziewięćdziesiątych jest wszak zaspokajaniem środkowoeuropejskiego poczucia zapóźnienia kulturowego za pomocą „necessary fiction”, która ma przypomnieć rodakom, że jeśli konfrontacja ze światem Zachodu okaże się nieudana, zawsze pozostanie nam rodzimy grajdoł, w którym możemy się czuć bezpiecznie, bo skrupulatnie chronimy go przed wszystkim, co nowe i obce.

Powieść Nic z 2005 roku otwiera fragment, który zapowiada swoiście resentymentalny charakter książki:

Miejscem, w którym dzieje się niniejsza historia, jest kraj w samym środku Wielkiego Niżu Europejskiego, rozległej równiny rozciągającej się od Paryża do Uralu. Tą płaską jak stół równiną raz po raz ciągnęły wielkie armie. Wszelkie wojska mogły się tędy

28 Sz. Twardoch, Wyznania prowincjusza. „Opcje” 2006, nr 4, s. 231.

„Kiedy gargantuiczne, nieprzystojne, nieco obleśne, rozlazłe, mające skłonność do przesady ciało polskie posłucha sarmackiego id i pokocha samo siebie, kiedy uzna, że nie musi się upiększać, chodzić na siłownię, stosować diet, utrzymywać linii i poddawać się reżimom edukacyjnym, wówczas nacisk wywierany przez autorytet nowoczesności na zacofane masy ustanie. (...) Jeśli nowoczesność była prawodawczynią wstydu, to koniec wstydu powinien być końcem modernizacji." P. Czapliński, op. cit., s. 112-113. 
przemieszczać, nie napotykając większych przeszkód naturalnych, pozostawiając po sobie zgliszcza i trupy ${ }^{29}$.

I dalej, kiedy mowa o bohaterach powieści:

(...) kiedy już zaczniemy śledzić perypetie bohaterów, zobaczymy, że są całkowicie pochłonięci małymi pragnieniami, przyziemnymi pasjami, odsuwają od siebie pytanie: z której strony przyjdą tym razem?

Pamiętajmy również, $\mathrm{w}$ jak szczególnym momencie zaczynamy ich podpatrywać. Oto wkoło zaczyna się wielka przemiana. Wydaje się nawet, że kraj, w którym żyją, wreszcie będzie mógł żyć po swojemu, a stało się tak, mimo że nie wkładali na siebie mundurów, nie repetowali broni. Historia okazała się tym razem dla tego miejsca wyjątkowo łaskawa ${ }^{30}$.

Po pierwsze zatem, mamy do czynienia z tzw. powieścią przełomu, która siłą rozpędu i oczekiwań krytyków dotyka kwestii historiozoficznych, po drugie - jak się wydaje - przedmiotem jej zainteresowania jest właśnie ten środkowoeuropejski fatalizm, który tak irytuje Ewę Thompson ${ }^{31}$. Swój wyraźnie antykolonialny kompleks wykrzykuje jeden $\mathrm{z}$ bohaterów powieści, entuzjastyczny menadżer $\mathrm{w}$ francuskiej sieci restauracji fast-foodowych „Positive”, były opozycjonista, nauczyciel historii, posądzany przez dawnych wykładowców o zbyt emocjonalny stosunek do materii studiów:

Czy ktoś jeszcze pamięta, co tu było cztery lata temu? Czy pamięta, że ten kraj był okupowany, że car dopiero przed miesiącem zabrał wreszcie ostatnich swoich generałów?32

Bieńkowski szkicując postać do tego stopnia zaangażowaną w korporacyjne życie, że rezygnującą lub niezdolną do zorganizowania sobie prywatności, przewrotnie daje do zrozumienia, że taki bohater jest jednocześnie podatny na postkolonialny kompleks Wschodu (jak to widać w powyższym fragmencie) i zachodni mit przyspieszonego rozwoju. Jest więc idealnym bohaterem negatywnym z tekstu Ewy Thompson: ma poczucie doznanej historycznej krzywdy, ale chce przestać ją rozpamiętywać, by wydobyć Polskę i Polaków z postkolonialnej stagnacji (,JJuż tak miałem dosyć tego: Bądź wierny, idź!"), skrycie gardzi ale i obawia się Rosjan, uważa ich za „niecywilizowanych dzikusów” i „dziadostwo". Potrzeba odcięcia

${ }^{29}$ D. Bieńkowski, Nic. Warszawa 2005, s. 7.

30 Ibidem, s. 7-8.

${ }^{31}$ Skądinąd podobne "geograficzne" wyjaśnienie historycznych wolt, jakie mają miejsce w tej części Europy stało się czymś w rodzaju toposu: znajdziemy je u Andrzeja Stasiuka, Josefa Kroutvora i innych środkowoeuropejczyków. Por. A. Stasiuk, J. Andruchowycz, Moja Europa. Dwa eseje o Europie zwanej Środkowa. Wołowiec 2007, J. Kroutvor, Europa Środkowa: anegdota i historia. Przeł. J. Stachowski. W: Hrabal, Kundera, Havel... antologia czeskiego eseju. Kraków 2001, s. 223-291.

${ }^{32}$ D. Bieńkowski, Nic, op. cit., s. 17. 
się od wspomnień o upokarzającej niewoli, popycha go na przeciwległy biegun zła: pracoholizm i kulturę korporacyjną. Ulubiona przez Bieńkowskiego narracyjna konwencja monologu wypowiedzianego pozwala na ironiczną grę $\mathrm{z}$ tym światopoglądem. Dzięki punktowi widzenia bohaterów, w których stopniowo narasta lęk i dystans wobec Zachodu, obserwujemy, jak po początkowym zachłyśnięciu się modernizacją powraca umiłowanie prowincjonalności: bo oto jedna z położonych niedaleko krakowskiego Wawelu kamienic zostaje przekształcona w fastfood, bo francuski szef pogardliwie traktuje Polskę jako kraj z grupy „rozwijających się", choć wykształceniem znacznie odbiega od swoich polskich pracowników, bo upada polski przemysł i polska kuchnia, bo nie wystarcza czasu na życie rodzinne i pielęgnowanie tradycji:

To ważne, żeby w każdym miejscu naszego Positive'a czuć się dobrze, ale teraz, jak lecą kolędy, to, cholera, jakoś tak nie pasuje... człowiek sra, a tu Bóg się rodzi, moc truchleje... pojutrze, cholera, Wigilia... Chociaż jaką gałązkę człowiek by przystosował, nastrój świąteczny w domu zrobił... Kurna Olek... gdzie by o tym pamiętać teraz?... Wszystko z głowy wyparowało... Na cmentarz do rodziców trzeba by iść... przecież to święta... ale czy się zdąży...33

Konkluzja tej powieści Bieńkowskiego jest zgodna z „sarmackim” modelem lansowanym przez Ewę Thompson - nie tylko dlatego, że kończy się sceną wielkiej uczty i poloneza z sarmackim przepychem-i "prowincjonalnym” Szczepana Twardocha: zachowajmy wypracowaną przez wieki „normalność”, czyli dystans do tego, co nam kulturowo obce i wróćmy do tradycyjnych wartości: braku wymuszonego uśmiechu, sposobu spędzania świąt, troski o rodzinę, pamięci o zmarłych, aktywności politycznej (paradoksalnie, w nowym systemie brakuje czasu na chodzenie na wybory), lokalnej kuchni, skromnej uprawy własnego ogródka, seksu przeżywanego $\mathrm{w}$ intymności, a nie $\mathrm{w}$ internecie, filmach porno i gazetach, spokojnego rytmu życia sprzed czasów Wielkiej Zmiany.

O ile Nic pozwala zarysować konflikt pomiędzy kapitalizmem i sarmatyzmem, tak kolejna powieść Bieńkowskiego - Biało-czerwony - w całości traktuje o sarmatyzmie, przede wszystkim w kontekście dialogu pokoleń i kryzysu męskości. Zadajmy więc głównemu bohaterowi powieści pytanie, które postawił niegdyś Stefan Chwin narratorowi Trans-Atlantyku:

Jak wywalczyć sobie duchową niezależność (i własną wybitność!) w starciu z „,centrum”, jeśli przynależymy do zbiorowości kulturowo „słabszej” z obrzeży, z peryferii? ${ }^{34}$

Trudno uznać, że w Biało-czerwonym punktem wyjścia jest kompleks prowincji - jest nim raczej niezgoda na równouprawnienie kobiet. Główny bohater-narrator

33 Ibidem, s. 63.

34 S. Chwin, Gombrowicz i Forma polska. W: W. Gombrowicz, Trans-Atlantyk. Kraków 1996, s. 140. 
- prawnik, właściciel kancelarii, mąż i ojciec - w przerysowanym i stylizowanym na gawędę szlachecką monologu wyraża sprzeciw wobec pracy zawodowej żony, która wymusza na nim przejęcie części domowych obowiązków, takich jak opieka nad pięcioletnim synem. W sukurs nieporadnemu Pawłowi przychodzi groteskowy Dziadek, a być może Ojciec, ucieleśniający idee sarmacko-powstańcze, PosełMinister oraz Teściowa Matka. Wszyscy oni opowiadają się za utrwalaniem tzw. tradycyjnego podziału obowiązków $\mathrm{w}$ rodzinie i nie pochwalają emancypacyjnych planów żony głównego bohatera. Dziadek daje wyraz swemu niezadowoleniu na przykład w takim monologu:

Powiedz mi, mój synu, jak to wszystko właściwie ma być, kiedy jej cały dzień nie ma w domu? Nic nie czeka przygotowane na stole. Stół pusty, a jej nie ma! (...) I jaki tego efekt? (...) Nie ma zupy! Zupa jest nieprzygotowana! Zupa nie paruje na stole! (...) Przecież jak można walczyć, jak można wydawać rozkazy, kiedy zupa nie czeka. Zupa! (...) Kiedy tak w śnieżycy podjeżdżaliśmy na koniach do majątku, a przez dwie doby kluczyliśmy, żeby zgubić za sobą kozaków... Albo tę zupę w piwnicy, kiedy schodziliśmy w kurzu i znoju z barykady. Zupa! (...) A teraz nie ma kto zrobić zupy, kiedy cały dzień jej w domu nie ma! A gdyby tak trzeba było zejść do podziemia, być $\mathrm{w}$ konspiracji i powstanie trzeba by wzniecić, to co wtedy? Kto przeniósłby meldunki i rozkazy? No, kto? Zawsze czekała. I mogłaby w każdej chwili stać się łączniczką czy sanitariuszką?

„Męskie” czynności i atrybuty w powieści Bieńkowskiego to: oglądanie meczu, posiadanie drogiego samochodu, zapewnianie rodzinie odpowiedniego statusu materialnego, zdradzanie żony, picie alkoholu, prowadzenie samochodu po pijanemu. „Kobiece” - uznawane przez narratora za uwłaczające jego godności - to: przygotowywanie posiłków, zaspokajanie popędu seksualnego mężczyzn, opieka nad potomstwem. Sarmackość objawia się nie tylko za sprawą oczywistej formalnej aluzji do Trans-Atlantyku (monolog stylizowany na gawędę, groteskowo wyolbrzymione zachowania, arbitralny zapis wybranych słów kluczy wielką literą), ale poprzez splot kultu męskości z tożsamością narodową. Na jego straży stoi nie tylko główny bohater-prawnik, ale także politycy, starsze pokolenia kobiet i mężczyzn, ksiądz i policja. Jedyną drogą ucieczki dla dążącej do równouprawnienia bohaterki jest oderwanie się od ziemi - co dzieje się w finalnej scenie powieści, którą można odczytywać jednocześnie jako ucieczkę i figurę uświęcenia. Kluczowym pojęciem konstrastującym z ową „sarmackością" jest właśnie „nowoczesność". O nowoczesności wspomina również Stefan Chwin w posłowiu do TransAtlantyku, pisząc, że w tej powieści sarmatyzm paradoksalnie staje się jej językiem. Można się zgodzić, że dzieje się tak za sprawą "estetycznej wspaniałości”, która odsłania się $\mathrm{w}$ „kuligach, polowaniach, pojedynkach, ślubach, zajazdach, etc." 36 .

\footnotetext{
35 D. Bieńkowski, Biało-czerwony. Warszawa 2007, s. 53.

${ }^{36}$ S. Chwin, op. cit., s. 143.
} 
Takie bogactwo jest znakomitym tworzywem dla języka groteski i karnawalizacji, praktykowanego przez postmodernizm. O takiej - płodnej, bo nieksenofobicznej odsłonie sarmatyzmu pisze także Przemysław Czapliński, omawiając powieść Michała Witkowskiego pt. Barbara Radziwiłłówna z Jaworzna-Szczakowej. Tutaj sarmatyzm staje się językiem „estetyki tak złej, że aż dobrej”37, tworzywem kampowych eksperymentów, językiem subwersji. Wydaje się, że Chwin stawia jednak przede wszystkim na drugą - tożsamościową - odsłonę sarmatyzmu, kiedy pisze:

Tylekroć ośmieszany szlachcic polski z epoki saskiej, poddany w powieści groteskowej hiperbolizacji, nagle okazuje się wzorem nowoczesnego sobiepańskiego stosunku do świata i duchowej suwerenności! ${ }^{38}$

Od owego „sobiepańskiego" stosunku do świata, która ma być strategią leczenia Polaków z modernizacyjnych kompleksów, blisko do tożsamościowej terapii, jaką wobec polskich postkolonialnych resentymentów proponuje Ewa Thompson. Nie o teatralizowanie egzystencji, od-grywanie życia, chodzi bohaterom Bieńkowskiego, ale o utrzymanie obyczajowego status-quo. Wyzwolenie z tej Formy poprzez wybuch śmiechu - jak w Trans-Atlantyku - w powieści Bieńkowskiego nie może mieć miejsca - bo jego bohater definiuje sam siebie w opozycji do „nowoczesnego mężczyzny", a jego postsarmacki język pozostaje językiem wykluczania, ksenofobii i zaściankowości.

\section{TROPY DWUDZIESTOLECIA}

Wspomniałam już, że neccesary fiction powstaje z dialogu literatury z krytyką literacką. Ta pierwsza dostarcza "tworzywa”, druga - ogłasza ciągłość, wskazuje pokrewieństwa, sankcjonuje intertekstualne continuum. Szczególnie wyrazistym przypadkiem takiej „fikcji” $\mathrm{w}$ polskiej literaturze najnowszej jest powinowactwo dwudziestowiecznych przełomów związanych z odzyskaniem niepodległości: roku 1918 i 1989. Kiedy jeden z bohaterów powieści Nic Bieńkowskiego zauważa entuzjastycznie:

Ale ja wiem, że mam rację! Doświadczamy teraz momentu na miarę roku tysiąc dziewięćset osiemnastego. I warto się tym szaleństwem zachłysnąćç3.

... buduje literacką parafrazę tekstu Jana Błońskiego z 1990 roku, w który badacz stwierdzał: Rok 1989 jest równie ważny co rok 19180. W jego ślad poszli kolejni

\footnotetext{
37 P. Czapliński, op. cit., s. 133.

38 S. Chwin, op. cit., s. 141.

39 D. Bieńkowski, Nic, op. cit., s. 17.

40 J. Błoński, Rok 1989 jest równie ważny co 1918. „Na Głos” 1990, nr 1, s. 60.
} 
krytycy: Jerzy Jarzębski, Przemysław Czapliński, Piotr Śliwiński, Tomasz Fiałkowski a także autorzy, jak choćby Marcin Świetlicki w znanym wierszu Pogo, czy Krzysztof Koehler w manifeście pod znamiennym tytułem Nowi skamandryci?. Trzeba jednak podkreślić, że "necessary fiction” dwudziestolecia jest zjawiskiem związanym przede wszystkim z krytyką literacką, mniej zaś z literaturą. Swoista "fikcja ciągłości" jest tak silna, że Marian Stala zaledwie trzy lata temu powrócił do tekstu Błońskiego, pisząc, że badacz Witkacego i Gombrowicza wyjawiał w nim swoje marzenie i stawiał poprzeczkę poetom debiutującym w latach dziewięćdziesiątych. I choć im dalej Stala popycha to porównanie, tym mniej znajduje podobieństw, nie rezygnuje z interpretacyjnego tła dwudziestolecia, w którym tkwi swoista konieczność:

Zasadniczym tłem wierszy pisanych bezpośrednio po roku 1918 i po 1989 były (by posłużyć się formułą Piotra Śliwińskiego) „przygody z wolnością". Czy była to ta sama przygoda, to samo pojmowanie i doświadczenie wolności? Nie podejmuję się udzielić natychmiastowej odpowiedzi. Intuicyjnie rzecz biorąc wolność młodych poetów lat dwudziestych zdaje się i bardziej wielokształtna, i bardziej pozytywna od wolności młodych poetów lat dziewięćdziesiątych. Łączą ich głównie gesty anarchistyczne ${ }^{41}$.

Trop dwudziestolecia jest obecny w nie tylko debatach nad kondycją polskiej poezji po 1989 roku. Powraca także w politycznych sporach nad - nazwijmy to możliwie ogólnie - pożądanym balansem sił pomiędzy władzą ustawodawczą i wykonawczą, sposobem celebracji świąt narodowych etc. Przywołuje się go także w kontekście postkolonialnym. Fikcja tej ciągłości jest - chyba jeszcze bardziej niż w przypadku sarmatyzmu i słowiańskości - konieczna, ale i niemożliwa. W literaturze polskiej po 1989 roku więcej znajdziemy tęsknot za (nierzadko wyidealizowaną i rzekomą) idyllą wielokulturowej Rzeczpospolitej lat dwudziestych i trzydziestych niż odwołań do spójnego projektu wspólnotowego.

Powieścią, w której trop międzywojnia powraca jako forma rozrachunku z zaściankową Polską lat dziewięćdziesiątych XX wieku jest Niehalo Ignacego Karpowicza. Figurą „koniecznej” ciągłości staje się w niej stojący w centrum Białegostoku pomnik marszałka Józefa Piłsudzkiego, który ucieleśnia rehabilitowane po przełomie - $\mathrm{w}$ dyskursie publicznym, literaturze i debacie nad nią - polskie idee mocarstwowe. Wspomnienie międzywojnia podszyte jest nostalgią: współczesny Białystok to w powieści Karpowicza, w ustach jego narratora, miasto tak „niszowe, że prawie go nie widać na mapie" 42 , „niepolska” 43 , gdzie kontrast pomiędzy kreowaną przez media wizją potransformacyjnej szczęśliwości a rzeczywistą

${ }^{41}$ M. Stala, 1989: Dwa dwudziestolecia (jednej epoki). „Dwutygodnik” 2009, nr 8, http:/ / www.dwuty godnik.com/artykul/284-1989-dwa-dwudziestolecia-jednej-epoki.html, data dostępu: 20.04.2013.

42 I. Karpowicz, Niehalo. Wołowiec 2006, s. 14.

${ }^{43}$ Ibidem, s. 19. 
i wielowymiarową nędzą mieszkańców wypada szczególnie dotkliwie. Ubogi świat sfrustrowanych ludzi („Oni przetrzymali komunizm, przetrzymają demokrację oraz atomowy wybuch" 44 ) dotyka jeszcze jedno nieszczęście - nastroje cywilizacyjnego upadku w związku z wstąpieniem Polski do Unii Europejskiej i towarzyszące im, wspierane ultrakatolickim światopoglądem, poczucie kresu tradycyjnego porządku etycznego. Symbolami minionego, lepszego „wczoraj” są pomniki Jerzego Popiełuszki i Józefa Piłsudskiego. W ich postaciach symbiotyczną więzią połączone są dwie polskie „normalności”: normalność religijna - w opozycji do radiomaryjnej -oraz patriotyczna - w kontraście do wszechpolskiej. W tej prowincjonalnej wizji Piłsudski nabiera rangi polityka, który przywrócił Polsce należną jej rangę wśród państw europejskich:

Ale jeden oldkulowy kul gościu, Józio Piłsudski, co miał fajne ciuszki i niezłego fioła, on tak namącił, że Polska znowu była na mapie. I my, Polacy, znowu dostaliśmy okazję, żeby wszystko rozpiździć. I prawie nam się udało (...). (58)

Główny bohater-narrator Niehalo nie identyfikuje się i nie rozumie podszytego patosem bezrefleksyjnego (?) patriotyzmu rodem z komunistycznych szkolnych apeli. Ten polski patriotyzm jest "bezcielesny” dyktuje fizjologiczne tabu. Żadna ludzka i cielesna niedoskonałość nie może mu sprostać. „Moja wojna z ojczyzną jest sprawą prywatną"45 -mówi. „Nigdy nam się razem nie układało"46. I chociaż względem większości wspólnotowych wartości i ich grupowych manifestacji bohater okazuje daleko idącą pogardę, Popiełuszko i Piłsudski wzbudzają jego szacunek. Marszałkowi, składając biało-czerwone goździki u stóp jego pomnika, wyznaje: „Chciałem przeprosić, że źle o panu myślałem. Oraz chciałem powiedzieć, z całym szacunkiem, że nie warto było o taką Polskę walczyć." 47 . Piłsudski obiecuje mu ukazać sens ponurej, białostockiej codzienności. W surrealistycznej wizji „Zwijania rzeczywistości”, której efekt stanowi „absolutne nic”, jedynym punktem odniesienia pozostaje on sam. Obaj z Popiełuszką mają dystans do Polski doby transformacji, a w szczególności do patriotyczno-katolickiego starszego pokolenia, które nazywają "hipopotamami”. "Necessary fiction” Karpowicza opiera się na przeciwstawieniu patriotyzmu Mickiewiczowsko-Kościuszkowskiego (martyrologicznego, powstańczego, ksenofobicznego i antyunijnego, wyznawanego przez Wszech Polaków i hipopotamice) pana Pollaka i Generałowej - zaskakującemu mariażowi „intelektualnego" katolicyzmu Jerzego Popiełuszki oraz „optymistycznego" tradycjonalizmu Józefa Piłsudskiego. W jego powieści dochodzi do podwójnego zerwania: współczesnej niepodległości z niepodległością międzywojnia

\footnotetext{
${ }^{44}$ Ibidem, s. 29.

45Ibidem, s. 85.

46Ibidem.

47Ibidem, s. 127.
} 
oraz z wizją niepodległości z czasów PRL-u. Pointą tej zawiłej historiograficznej wizji jest zdanie wypowiedziane przez Marszałka do Popiełuszki: "- Przestań wreszcie - mówi podnosząc się. - To niezdrowo rozpamiętywać przeszłość" 48 .

Podsumowując: polski dyskurs tożsamościowy po 1989 roku konstruuje kilka "necessary fictions", w większości umacniających w narodzie poczucie dziejowej krzywdy, co jest dowodem na jego zasadniczo postkolonialną naturę. W omówionych powyżej tekstach projektowana w czytelniczym odbiorze konieczność góruje nad fikcjonalnością. Trzeba jednak podkreślić, że podobne historyczne ciągłości, choć niektóre $\mathrm{z}$ nich wykazują niezwykłą trwałość, powstają równie szybko, co ulegają demontażowi, a literatura, która się nimi posiłkuje, często czyni to na prawach postkolonialnej gry i ironii.

48Ibidem, s. 185. 